\title{
Characteristics of the Journal Literature of Bibliographic Instruction
}

\author{
James K. Bracken and John Mark Tucker
}

The citations in 187 articles on bibliographic instruction published in thirteen library science journals were analyzed to determine the extent to which authors cited sources from library and information science compared to sources from traditional subject disciplines. The results suggest an insularity of user instruction literature not only from other subject disciplines but from the larger field of librarianship as well.

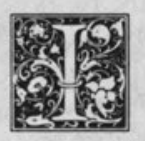

n 1979 Deborah Lockwood urged instruction librarians to "begin reaching beyond the library field," to "start thinking in broader terms than individual programs," and "to develop a philosophy and a concept" of bibliographic instruction that would appeal both to professional librarians and to library users. ${ }^{1} \mathrm{Re}$ lated sentiments had been stated a year earlier by Jon Lindgren, who decried the librarian's lack of a "discoverable" body of theory and a methodology-necessary foundations for the advance of user instructional efforts. Lindgren repeated those concerns in 1982, calling for proponents of bibliographic instruction to communicate how access to reference and bibliographic sources relates to the "intellectual and not mechanical" processes of library research and library use. ${ }^{2}$ Lindgren's later study was one chapter in a book that signaled the growing sophistication of instruction librarians, Theories of Bibliographic Education, a collection of essays intended to "remedy the absence of theory-based instruction literature. ${ }^{\prime \prime 3}$ Five years later this issue found expression in Conceptual Frameworks for Bibliographic Education, another collected work.

A desire for the literature to reflect stronger conceptual underpinnings seemed almost implicit in Hannelore Rader's introductions to her annual bibliographies of publications about user instruction. Yet, in reporting on the literature for the period from 1980 to 1985 , she goes one step further by nurturing the perception that a change in the nature of the literature has been occurring. She chronicled an apparent advance by noting in 1981 that although many publications provided only program descriptions, a growing number were theoretical. ${ }^{5}$ A year later she detected the dominance of program descriptions coupled with a concern for evaluation and theoretical frameworks, an observation repeated again the following year. In both 1984 and 1986 Rader wrote that the number of publications dealing with theory and research was increasing and that these publications were appearing in

James K. Bracken is Head, Second Floor Information Services, Bibliographer for English, Communication and Speech and Assistant Professor, University Libraries, Main Library, Ohio State University, Columbus, Ohio 43210. John Mark Tucker is Senior Reference Librarian and Professor of Library Science, Purdue University, West Lafayette, Indiana 47907. 
discipline-oriented journals and resulted from librarians' closer association with other professionals and professional associations.

With the comments by Lockwood, Lindgren, and Rader in mind, the authors analyzed the literature of bibliographic instruction to find out to what extent authors in this field were reaching beyond their own subfield to make use of sources in traditional subject disciplines. Although our interest in a stronger theoretical base has stimulated our inquiries, we have not assumed that the mere citing of a publication from a subject indicates the presence of successful theory construction. We have assumed, however, that the use of a source from these or other disciplines indicates an interest in a relationship that would ultimately serve the educational purposes of the discipline and honor the professional commitments of instruction librarians.

Additional objectives included the development of a core list of journals to which practitioners and educators would automatically turn in search of the latest trends. Our findings are displayed to show readers which journals have established themselves as more or less dependent on scholarship from the subject disciplines, as well as which journals tend to rely on more current (or comparatively more retrospective) sources in articles they accept for publication.

A final objective was to determine which contributors to the literature of bibliographic instruction are cited most often. In some instances we suggest why an individual is cited with a high degree of frequency. The presence or absence of a strong core of heavily cited personal authors is an important factor in understanding the characteristics of professional literatures. According to writings on citation analysis, a frequently cited publication is a measure of the utility of that particular publication, not a judgment of its importance or impact. ${ }^{6}$

\section{REVIEW OF THE LITERATURE}

The tendency of library science authors to cite their own literature (a tendency that Penelope Earle and Brian Vickery define as "self-citation") ${ }^{7}$ and cite less frequently disciplines outside the field has been widely observed and largely interpreted as indicating the insularity of library science from outside influences. In an analysis of articles in the Journal of Education for Librarianship for the period 1960 through 1970, Donald Lehnus noted that 64 percent of cited works were from the literature of library science, while 14 percent were from education and 22 percent were from outside both library science and education. ${ }^{8}$ Tim LaBorie and Michael Halperin discovered that over half ( 58 percent) of the references in 186 doctoral dissertations in library science completed between 1969 through 1972 were to library and information science literature. They concluded that the pattern of self-citation suggests that research in library science was "less interdisciplinary than that within the social sciences in general. "' They also found that the fields of history, geography, and anthropology contributed 13.7 percent and education contributed 7.9 percent (p.276). Observing that the percentage of citations to works outside a particular discipline indicates the extent to which that discipline is "open to influences from other fields," Bluma Peritz found that 78 percent of the citations from research articles appearing from 1950 through 1975 in a core list of thirty-nine library science journals were from the field of library and information science. Peritz judged this "a very high value, which seems to indicate very little interaction with other fields," adding that "it seems fair to conclude-at least tentatively - that there is, in this literature, no trend towards opening up to outside influences. ${ }^{10}$ In analyses of 3,655 citations from 317 articles from the Journal of Education for Librarianship from the period 1960 through 1984, Alvin Schrader anticipated that researchers in library science education would "look to the literature of education for pedagogic theories, philosophies, principles, and practices," but in fact found that "JEL authors cited 22 education journals about four times each," or only about 2 percent, and further noted that "no other field provided more than one or two journals for citing except psychology with 11 titles which re- 
"Pierce argues that because professionals, like librarians, focus on their own problems, they draw from 'a much narrower range of subject literatures' than researchers in the sciences."

ceived 37 citations," or about 1 percent (p.288-95). ${ }^{11}$

Most recently, Sidney Pierce suggests that library science authors are largely insular in the materials they cite. Pierce argues that because professionals, like librarians, focus on their own problems, they draw from "a much narrower range of subject literatures" than researchers in the sciences. ${ }^{12}$ Lehnus could identify only ten authors whose works were cited six or more times in the same period. William Brace observed an absence of a substantial core of personal authorities in an analysis of 202 dissertations. ${ }^{13}$ Only 2,419 of 8,474 authors were cited more than once. The American Library Association was the most frequently cited author $(2,152$ citations). Schrader pointed out that "less than one percent of all 1,950 cited authors received nine percent of all citations, while 70 percent received only one citation." Similar to Brace, Schrader found that the most frequently cited author (corporate or personal) was the American Library Association, "receiving twice as many citations as the next ranked author (p.294)."14

\section{METHODOLOGY}

This article began by identifying articles that Hannelore Rader described as dealing with bibliographic instruction either in all areas of librarianship or in academic librarianship exclusively. The articles appeared in eleven American and two European library science journals, including American Libraries, College \& Research Libraries, College \& Research Libraries News, Journal of Academic Librarianship, Journal of Librarianship, Library Journal, Library Trends, Libri, and $R Q$, which are generally recognized as "core journals" of library science.
S. Nazim Ali noted that 72 percent of the Illinois librarians responding to his survey indicated a preference as well as a dependence on familiar and readily available practitioner-oriented journals for information on research in this field. ${ }^{15}$ Rader also listed a number of articles published in Catholic Library World, Research Strategies, Reference Librarian, and Reference Services Review. From this core list of thirteen journals, we identified a total of 312 articles, after excluding 107 articles, or 33.4 percent, that had no footnotes and 18 more that were bibliographies and opinion columns (such as those regularly appearing in the Journal of Academic Librarianship and $R Q)$. We submitted 187 articles to citation analysis. These analyzed articles contained 2,882 citations to specific sources and 2,988 citations to personal authors, exclusive of corporate authors. The citations were categorized by subject or discipline of the work cited, type of work cited, and author(s) cited. Multiple authors were given equal value with individual authors.

\section{RESULTS}

As demonstrated in table 1, authors of articles on bibliographic instruction cite publications in library science about three times as frequently as they cite publications from other fields. Of the 2,882 footnotes listed in 187 articles, 2,145 (74.43 percent) cited library science sources while the remainder, 737 ( 25.57 percent) cited sources in disciplinary and interdisciplinary subjects. Following library sci-

TABLE 1

\section{SUBJECTS RANKED BY NUMBER AND PERCENTAGE OF CITATIONS*}

\begin{tabular}{lrc}
\hline \hline Subject & $\begin{array}{c}\text { Number of } \\
\text { Citations }\end{array}$ & $\begin{array}{c}\text { Percentage of } \\
\text { Total }\end{array}$ \\
\hline Library science & 2,145 & 74.43 \\
Education & 403 & 13.98 \\
Interdisciplinary & 85 & 2.95 \\
$\quad$ subjects & 56 & 1.94 \\
Psychology & 36 & 1.25 \\
English & 30 & 1.04 \\
Information science & 127 & 4.41 \\
All others combined & 2,882 & 100.00 \\
\hline \multicolumn{1}{c}{ Totals } & &
\end{tabular}

•Based on citations from 187 footnoted articles about academic library use instruction published in twelve journals from 1980 through 1985 . Subjects listed separately are those receiving at least 1 percent of the total. 
ence was education with 403 (13.98 percent)-a natural choice given the nature of bibliographic instruction as an educational process. Citations to publications in interdisciplinary fields were, generally speaking, those easily recognized as interdisciplinary, for example, history and political science, religion and philosophy, education and sociology. Two disciplines that were cited more than 1 percent of the time were psychology (1.94 percent), defined to include psychiatry, and English (1.25 percent), defined to include English and American literature produced in the Americas, Australia, India, South Africa, and the United Kingdom. Information science, cited with 1.04 percent frequency, was separated from library science as the former has established its own professional, academic, and bureaucratic identity apart from schools of librarianship. Literature in the broad areas that encompass library and information science is, for purposes of this paper, defined as the literature of library science only. All other disciplines combined were cited with 4.41 percent frequency. These include art, communication, computer science, economics and management, geography, history, law, medicine, music, philosophy, political science, religion, sociology, and technology.

Table 2 ranks journals publishing five or more articles about bibliographic instruction in the years from 1980 to 1985 according to the frequency with which their authors cited disciplinary and interdisciplinary sources. During the period covered in this study, Catholic Library World published eleven articles that collectively included seventy-one citations, thirty (42.2 percent) of which represented sources from a subject discipline. Placing second behind Catholic Library World was Research Strategies, a relatively new journal devoted to library concepts and instruction, that published forty-nine papers containing 372 citations from its inception in 1983; of the 372 citations 149 (40.1 percent) were drawn from subject and interdisciplinary sources.

Only one other journal, College $\& R e$ search Libraries, showed a figure higher than our average for nonlibrary science citations of 25.57 percent. It published twenty-three papers containing 432 citations of which 136 (31.5 percent) were drawn from subject and interdisciplinary sources. Other journals in table 2, ranked according to percentages of nonlibrary science citations in bibliographic instruction articles, are Journal of Academic Librarianship (21.8 percent), Reference Librarian (19.5 percent), $R Q$ (19.1 percent), Reference Services Review (17.8 percent), Library Trends (17.5 percent), and Libri (12.8 percent). While the overall figure in table 1 identifies 2,882 citations, the data shown in tables 2 and 3 are based on a total of 2,769 citations, since the latter tables exclude articles published in journals that issued fewer than five bibliographic instruction papers during the period studied.

Table 3 illustrates the concern of bibliographic instruction authors to cite the most current literature available. Assum-

TABLE 2

DISTRIBUTION BETWEEN LIBRARY SCIENCE AND DISCIPLINARY/INTERDISCIPLINARY CITATIONS*

\begin{tabular}{|c|c|c|c|c|c|}
\hline \multirow[b]{2}{*}{ Journal } & \multirow{2}{*}{$\begin{array}{c}\text { Articles/Citations } \\
\text { Number }\end{array}$} & \multicolumn{2}{|c|}{$\begin{array}{l}\text { Library Science } \\
\text { Citations }\end{array}$} & \multicolumn{2}{|c|}{$\begin{array}{c}\text { Disciplinary/ } \\
\text { Interdisciplinary } \\
\text { Citations }\end{array}$} \\
\hline & & Number & Percent & Number & Percent \\
\hline Catholic Library World & $11 / 71$ & 41 & 57.8 & 30 & 42.2 \\
\hline Research Strategies & $49 / 372$ & 223 & 59.9 & 149 & 40.1 \\
\hline College \& Research Libraries & $23 / 432$ & 296 & 68.5 & 136 & 31.5 \\
\hline Journal of Academic Librarianship & $23 / 243$ & 190 & 78.2 & 53 & 21.8 \\
\hline Reference Librarian & $19 / 323$ & 260 & 80.5 & 63 & 19.5 \\
\hline$R Q$ & $30 / 293$ & 237 & 80.9 & 56 & 19.1 \\
\hline Reference Services Review & $7 / 107$ & 88 & 82.2 & 19 & 17.8 \\
\hline Library Trends & $14 / 834$ & 688 & 82.5 & 146 & 17.5 \\
\hline Libri & $5 / 94$ & 82 & 87.2 & 12 & 12.8 \\
\hline
\end{tabular}

*Journals publishing five or more articles about academic library use instruction from 1980 through 1985. 
TABLE 3

DISTRIBUTION BETWEEN ARTICLE AND OTHER SOURCES (RANKED BY THE CURRENCY OF THE LITERATURE IN THEIR ARTICLES*

\begin{tabular}{lccccc}
\hline \hline & Citations & \multicolumn{2}{c}{ Other Sources } & \multicolumn{2}{c}{ Article Sources } \\
Journal & Number & Number & Percent & Number & Percent \\
\hline Reference Librarian & 323 & 50 & 15.5 & 273 & 84.5 \\
Journal of Academic Librarianship & 243 & 50 & 20.6 & 193 & 79.4 \\
Library Trends & 834 & 185 & 22.2 & 649 & 77.8 \\
Reference Services Review & 107 & 24 & 22.4 & 93 & 77.6 \\
RQ & 293 & 71 & 24.2 & 222 & 75.8 \\
Libri & 94 & 24 & 25.5 & 70 & 74.5 \\
College \& Research Libraries & 432 & 115 & 26.6 & 317 & 73.4 \\
Research Strategies & 372 & 109 & 29.3 & 263 & 70.7 \\
Catholic Library World & 71 & 26 & 36.6 & 45 & 63.4 \\
\hline
\end{tabular}

*Journals publishing five or more articles about academic library use instruction from 1980 through 1985.

ing that journal literature is more current than other sources, including monographs, the most current literature cited by authors of user instruction papers appears in the Reference Librarian. Some 273 (84.5 percent) of the 323 citations in this publication identified journal articles while only 50 ( 15.5 percent) cited books, collected works, dissertations, and other sources. Other periodicals whose contributors relied heavily on journal articles were Journal of Academic Librarianship (79.4 percent), Library Trends (77.8 percent), Reference Services Review (77.6 percent), $R Q$ (75.8 percent), Libri (74.5 percent), and College \& Research Libraries (74.3 percent).

Interestingly, those journals whose contributors were most likely to use disciplinary and interdisciplinary sources were those least likely to rely on current literature. Thus, the three journals ranking the highest in nonlibrary science citations, Catholic Library World, Research Strategies, and College \& Research Libraries, ranked lowest-precisely in reverse order-in their tendency to cite articles rather than monographs, collected works, or other sources. Stated differently, the journals ranking highest in library science citations cited the more current literature and the journals ranking highest in a mixture of disciplinary and interdisciplinary citations used comparatively more of the older monographic and other types of literature.

Citation analysis has long been recognized as a tool for understanding something of the influence of particular authors. According to table 4, contributors to the bibliographic instruction literature tend to cite prominent practitioners and, to a lesser degree, theorists and critics in the field. Approximately 1,324 personal authors accounted for a total of 2,988 citations, and 843 (64.7 percent) were cited once, while another 481 ( 36.3 percent) were cited two or more times each. Analysis of the latter group revealed that members of a discrete group of 51 personal authors ( 3.9 percent) were cited ten times or more each for a total of 927 . Thus, 51 individuals accounted for about 31 percent of the citations. Indeed, 1 percent of the total number of personal authors comprised 13 percent of all personal author references; in other words, more than one of ten personal author citations referred to Thomas G. Kirk, John Lubans, Raymond G. McInnis, Patricia B. Knapp, Pauline Wilson, Mary W. George, Sharon A. Hogan, Larry L. Hardesty, Anne K. Beaubien, Nancy Fjallbrant, William A. Katz, Anne F. Roberts, or Topsey N. Smalley.

\section{DISCUSSION AND CONCLUSION}

The results indicate an incidence of selfcitation in the literature of library user instruction that corresponds to previous findings for citations in library science literature in general. We found that 74.43 percent of the analyzed citations referred to sources in the field of library science, while 25.57 percent cited sources outside the field. Comparison of our results with previous studies of the incidence of selfcitations to library science suggests a general increase rather than a decrease in selfcitation over a period of time. Lehnus 
TABLE 4

AUTHORS CITED AT LEAST TEN TIMES (RANKED BY FREQUENCY*)

\begin{tabular}{lclc}
\hline \hline Author & $\begin{array}{c}\text { Number of } \\
\text { Times Cited }\end{array}$ & Author & $\begin{array}{c}\text { Number of } \\
\text { Times Cited }\end{array}$ \\
\hline Kirk, Thomas G. & 54 & Williams, Mitsuko & 15 \\
Lubans, John & 47 & Davis, Elisabeth B. & 14 \\
McInnis, Raymond G. & 44 & Downs, Roger M. & 14 \\
Knapp, Patricia B. & 29 & Kobelski, Pamela & 14 \\
Wilson, Pauline & 28 & Lancaster, F. W. & 14 \\
George, Mary W. & 27 & Lindgren, Jon & 14 \\
Hogan, Sharon A. & 27 & Lovrich, Nicholas P. & 14 \\
Hardesty, Larry L. & 26 & Reichel, Mary & 14 \\
Beaubien, Anne K. & 24 & Rothstein, Samuel & 14 \\
Fjallbrant, Nancy & 24 & Stoffle, Carla J. & 14 \\
Katz, William A. & 22 & Kennedy, James R. & 13 \\
Roberts, Anne F. & 21 & Hopkins, Frances L. & 13 \\
Smalley, Topsey N. & 21 & McCarthy, Constance & 12 \\
Werking, Richard Hume & 20 & Benson, James & 11 \\
Farber, Evan Ira & 19 & Dudley, Miriam & 11 \\
Rader, Hannelore B. & 19 & Gagne, R. M. & 11 \\
Young, Arthur P. & 19 & Hills, P. J. & 11 \\
Oberman-Soroka, Cerise & 17 & Kotler, Philip & 11 \\
Breivik, Patricia & 16 & Phipps, Shelley E. & 11 \\
Kirkendall, Carolyn A. & 16 & Green, Samuel Swett & 10 \\
Renford, Beverly & 16 & Hernon, Peter & 10 \\
Schiller, Anita & 16 & Lynch, Mary Jo & 10 \\
Frick, Elizabeth & 15 & Rice, James, Jr. & 10 \\
Gardner, Jeffrey J. & 15 & Stea, David & 10 \\
Mannon, James & 15 & Wiggins, Marvin & 10 \\
Nielsen, Brian & 15 & & \\
\hline & & & \\
\hline
\end{tabular}

*Based on citations from 187 footnoted articles about academic library use instruction published in twelve journals from 1980 through 1985.

found a 64 percent incidence of selfcitation in library education literature from 1960 through 1970, while Schrader found an incidence of approximately 90 percent in the same kind of literature for the period 1960 through 1984. Similarly, LaBorie and Halperin's study of library science dissertations indicated a lower incidence ( 58 percent) of self-citation than Peritz observed in the literature published since 1960. After this date, Peritz noted, the percentage of citations outside librarianship remains in the vicinity of 20 percent, with self-citation at about 80 percent. Our results indicate that the user instruction literature is almost as prone to selfcitation as that of library science in general. The strong pattern of self-citation in the literature of the user instruction subfield merely reflects patterns observed in the literature of librarianship generally.

We anticipated that the user instruction literature would draw substantially from the literatures of education and psychology. These assumptions were confirmed.
Frequencies of citations from sources in education (14 percent) and psychology ( 2 percent) were observed. This was similar to previous findings. Lehnus found a 14 percent incidence of education citation, while LaBorie and Halperin found 7.9 percent. Schrader observed that sources in education and psychology were the most frequently cited subject disciplines outside library science. Our findings suggest that one in six references cited sources from one of these two subjects.

While our results in the patterns of selfcitation were similar to those of previous studies, our results in personal author citations were considerably different. Indeed, we found a core group of fifty-one personal authors-nearly all practitioners in library science-upon whom the literature was largely dependent. These individuals accounted for almost one-third of all citations to personal authors in the period 1980 to 1985 . On the other hand, the sole personal author representing a subject discipline outside library science in 
this group-R. M. Gagne-was cited only eleven times. The cumulative citation of personal authors in this group dominated the literature of user instruction. This dependence on particular personal authors in the field of library science identifies user instruction as a subfield and suggests an insularity of its literature not only from other subject disciplines but from the larger field of librarianship as well. On a more positive note, self-citation conforms to the pattern that characterizes the literature of a highly developed profession.

"The most frequently cited individual from 1980 to 1985 was Thomas G. Kirk, who qualified as both a practitioner (through his instruction activity at Earlham and Berea colleges) and a researcher."

The most frequently cited individual from 1980 to 1985 was Thomas G. Kirk, who qualified as both a practitioner (through his instruction activity at Earlham and Berea colleges) and a researcher. Kirk reported the results of his master's thesis, "Comparison of Two Methods of Library Instruction for Students in Introductory Biology," in College \& Research Libraries (32:465-73 (1971)). John Lubans is known largely as an editor of collected essays but also as a journal author and as a practitioner/researcher from his years at the University of Colorado. Raymond G. McInnis was recognized for New Perspectives for Reference Service in Academic Libraries (Greenwood, 1978), a thoughtful monograph with serious implications for bibliographic instruction programs.

Because bibliographic instruction authors are sensitive to the most vocal critics of user instructional efforts, they have cited Anita Schiller, Pauline Wilson, William A. Katz, and Topsey N. Smalley with some frequency. Both Schiller and Wilson presented cogent, well-defined critiques in papers published in Library Quarterly: "Reference Service: Information or In- struction," (35:52-60 (1965)) and "Librarians as Teachers: The Study of an Organization Fiction,'" (49:146-62 (1979)), respectively. Katz was cited for the dim view of instructional programs he has taken in successive editions of his textbook on reference work and Smalley was cited for "Bibliographic Instruction in Academic Libraries: Questioning Some Assumptions," a timely essay that summarized a number of the concerns of contemporary practitioners, in Journal of Academic Librarianship (3:280-83 (1977)).

Finally, Richard Hume Werking and Arthur P. Young were cited for having produced evaluative summaries of some of the research literature of user instruction. Although the results of substantial research about this topic were relatively sparse, they gained recognition and appreciation among instruction advocates.

Our experience in academic librarianship and our knowledge of the literature of user instruction led us to expect that certain individuals would exert a more profound influence on the literature than they actually have. Among these were practitioner/authors Robert B. Downs, Louis Shores, and Harvie Branscomb (the last two of whom have known few peers in the history of bibliographic instruction), library science theorists S. R. Ranganathan and Patrick Wilson, educators Benjamin Bloom and Jerome Bruner, and psychologist Jean Piaget. Educational theorist R. M. Gagne is the only individual outside the profession to have been cited at least ten times.

Identification of a group of user instruction journals within the recognized core of library science journals, much like the pattern of personal author citations, further underscored tendencies toward insularity. About one-third of the literature lacked footnotes and was excluded from further analysis. These articles were concentrated in American Libraries, College \& Research Libraries News, Library Journal, and Journal of Librarianship-all journals that are heavily used by practitioners. Many research articles on library user instruction were, in fact, found to appear in two journals that are not as yet widely recognized as core journals-Research Strategies 
and Reference Librarian-as well as in College \& Research Libraries, Journal of Academic Librarianship, and $R Q$. Sources outside the field were more frequently cited in Catholic Library World, Research Strategies, and College \& Research Libraries. These journals also more frequently cited nonjournal sources. The ten other titles from our core of thirteen reflected higher frequencies of citation from the library science literature and current periodical literature.

\section{RECOMMENDATIONS FOR FURTHER STUDY}

The literature devoted to bibliographic instruction has been in print for more than a century. In that respect it roughly parallels the growth of library science literature in the United States. A citation analysis of earlier writings would indicate something of the origins and development of both literatures. Moreover, the present study deals only with the journal literature. Other monographs and collected works could be analyzed and compared with the journal literature. ${ }^{16}$

Of greater value are concerns about the inherent quality and purpose of the literature of bibliographic instruction, in particular, the presence or absence of research content. The importance of research to user instruction efforts is an issue that Rader continually raises in the introductions to her bibliographies. A study of the instruction literature, similar to that conducted by Caroline Coughlin and Pamela Snelson in their examination of papers presented at the first national ACRL conference, would, if conducted from a longitudinal viewpoint, either confirm or deny Rader's perception that such publications are increasing in number. ${ }^{17}$

Studies of randomly selected articles and monographs could be equally fruitful. Additional studies might consider the relative conformance of bibliographic instruction literature to the literature of librarianship and the professional and intellectual implications for librarianship if differences or similarities continue over several years. The instruction literature might profitably be compared to the literature of reference, cataloging, and other library functions. These studies should inform the dialogue that relates to the growing expertise and specialization of various interests within librarianship as compared to the negative aspects of the same trend, a diminishing sense of community and an increasing intellectual isolation within a rapidly splintering profession.

\section{REFERENCES}

1. Deborah L. Lockwood, Library Instruction: A Bibliography (Westport, Conn.: Greenwood, 1979), p.viii.

2. Jon Lindgren, "Seeking a Useful Tradition for Library Use Instruction in the College Library," in Progress in Educating the Library User, ed. John Lubans (New York: Bowker, 1982), p.74; and "The Idea of Evidence in Bibliographic Inquiry," in Theories of Bibliographic Education: Designs for Teaching, ed. Cerise Oberman and Katina Strauch (New York: Bowker, 1982), p.30.

3. Oberman and Strauch, Theories, p.viii.

4. Mary Reichel and Mary Ann Ramey, ed. Conceptual Frameworks for Bibliographic Education: Theory into Practice (Littleton, Colo.: Libraries Unlimited, 1987).

5. See Reference Services Review 9:79-89 (Apr. 1981); 10:33-41 (Summer 1982); 11:57-65 (Summer 1983); 12:59-71 (Summer 1984); and 14:59-69 (Summer 1986).

6. Eugene Garfield, "Is Citation Analysis a Legitimate Evaluation Tool?" Scientometrics 1:359-75 (1979); Alvin M. Schrader, "A Bibliometric Study of the JEL, 1960-1984," Journal of Education for Library and Information Science 25:279-300 (1985).

7. Penelope Earle and Brian Campbell Vickery, "Social Science Literature Use in the U.K. as Indicated by Citations," Journal of Documentation 25:123-41 (1969).

8. Donald J. Lehnus, "JEL, 1960-1970: An Analytical Study," Journal of Education for Librarianship 12:71-83 (1971).

9. Tim LaBorie and Michael Halperin, "Citation Patterns in Library Science Dissertations," Journal of Education for Librarianship 16:271-83 (1976).

10. Bluma C. Peritz, "Citation Characteristics in Library Science: Some Further Results from a Bib- 
liometric Survey," Library Research 3:47-65 (1981).

11. Schrader, "A Bibliometric Study," p.288-95.

12. Sidney J. Pierce, "Characteristics of Professional Knowledge Structures: Some Theoretical Implications of Citation Studies," Library and Information Science Research 9:143-71 (1987).

13. William Brace, "Frequently Cited Authors and Periodicals in Library and Information Science Dissertations," Journal of Library and Information Science 2:16-34 (1976).

14. Schrader, p.294.

15. S. Nazim Ali, "Attitudes and Preferences of Library Practitioners in Illinois to Channels for Dissemination of Research Results," College \& Research Libraries 47:167-72 (1986).

16. Beverly Renford and Linnea Hendrickson, Bibliographic Instruction: A Handbook (New York: NealSchuman, 1980); James Rice, Jr., Teaching Library Use (Westport, Conn.: Greenwood, 1981); Anne K. Beaubien, Sharon A. Hogan, and Mary W. George, Learning the Library: Concepts and Methods for Effective Bibliographic Instruction (New York: Bowker, 1982); Anne F. Roberts, Library Instruction for Librarians (Littleton, Colo.: Libraries Unlimited, 1982); Cerise Oberman and Katina Strauch, ed., Theories of Bibliographic Education: Design for Teaching (New York: Bowker, 1982); Association of College and Research Libraries, Bibliographic Instruction Section, Subcommittee on Evaluation, Evaluating Bibliographic Instruction (Chicago: American Library Assn., 1983); Mignon S. Adams and Jacquelyn M. Morris, Teaching Library Skills for Academic Credit (Phoenix, Ariz.: Oryx, 1985).

17. Caroline Coughlin and Pamela Snelson, "Searching for Research in ACRL Conference Papers," Journal of Academic Librarianship 9:21-26 (Mar. 1983). 